Jurnal IImiah Akuntansi dan Kenangan

http://journal.stieputrabangsa.ac.id/index.php/jiak

ISSN: 2580-510X/ P-ISSN: 2548-9453

ARTICLE INFORMATION

Received June $18^{\text {th }} 2019$

Accepted October $25^{\text {th }} 2019$

Published January $24^{\text {th }} 2020$

DOI:

10.32639/jiak.v91.313

\section{Analisis dan Kontribusi Sektor Basis Non-Basis: Penentu Potensi Produk Unggulan Kabupaten Kebumen}

\author{
Marynta Putri Pratama ${ }^{1}$ \\ 1) STIE Putra Bangsa Kebumen \\ email:mputripratama@gmail.com
}

\begin{abstract}
ABSTRAK
Metode penelitian yang digunakan dalam penelitian ini adalah Analisis LQ untuk mengetahui perubahan struktur/kinerja ekonomi daerah terhadap struktur ekonomi yang lebih tinggi (provinsi atau nasional) sebagai referensi dan Analisis Shift Share untuk menentukan kinerja atau produktifitas kerja perekonomian daerah dengan membandingkannya dengan daerah yang lebih besar (tingkat regional atau nasional). Penelitian ini mengambil data sekunder yang diperoleh dari data BPS. Berdasarkan hasil penelitian diketahui bahwa (1) komoditas Jagung, Ubi kayu, Ubi Jalar, Kacang Tanah dan Kedelai memiliki angka LQ> 1. Hasil ini menggambarkan lima produk ini menjadi produk basis di Kabupaten Kebumen. Perhitungan total shift share yang memicu pertumbuhan dengan cepat untuk Kabupaten Kebumen adalah komoditas padi sawah, jagung, ubi kayu, kedelai dan kacang hijau. Sedangkan ubi jalar dan kacang tanah belum mampu memicu pertumbuhan pertumbuhan sub sektor tanaman pangan di Kabupaten Kebumen.
\end{abstract}

Kata Kunci: Sektor basis dan non basis, Produk unggulan, Location Quotient, Shift Share

\title{
ABSTRACT
}

The research method used in this study is $L Q$ Analysis to determine changes in the structure / performance of the regional economy to a higher economic structure (provincial or national) as a reference and Shift Share Analysis to determine the performance or work productivity of the regional economy by comparing it with larger regions (regional or national level). This study takes secondary data obtained from BPS data. Based on the results of the study note that (1) the commodity of Corn, Cassava, Sweet Potatoes, Peanuts and Soybeans have a number of $L Q>1$. These results describe these five products being the base products in Kebumen Regency. Calculation of total shift share that triggers rapid growth for Kebumen Regency is commodity of paddy, maize, cassava, soybeans and green beans. While sweet potatoes and peanuts have not been able to trigger growth in the growth of the food crops sub-sector in Kebumen Regency

.Keywords: Basic dan Non basic sector, Featured product, Location Quotient, Shift Share 


\section{PENDAHULUAN}

Indonesia merupakan negara kepulauan yang terletak di garis khatulistiwa yang menjadikan negeri ini sebagai negeri tropis yang sangat kaya dalam hal keanekaragaman hayati. Sebagai negeri yang memiliki hutan hujan tropis, Indonesia seperti daerah lainnya mempunyai kondisi lingkungan yang basah dan lembab. (Suharna, 1993).Indonesia merupakan negara agraris yang memiliki potensi besar dan sumber daya alam yang melimpah untuk produk pertanian. Di sektor pertanian Indonesia memiliki beragam jenis tanaman, hal ini didukung kondisi iklim tropis yang berbeda, dibidang tanaman pangan di Indonesia memiliki tanaman unggul seperti padi, kedelai, kacang tanah, ubi kayu dan berbagai jenis varietas yang lain.

Kebijakan pembangunan pertanian merupakan salah satu kebijakan pembangunan nasional yang sangat penting dan besar pengaruhnya dalam pembentukan ketahanan nasional. Hal ini disebabkan karena ketahanan pangan dan gizi merupakan salah satu komponen dalam ketahanan ekonomi, tanpa ketahanan pangan yang memadai, mustahil dapat menjawab perubahan yang mendasar yang akan terjadi dimasa mendatang. Pada saat sekarang dan masa datang, sektor pertanian masih memegang peranan penting dalam pembangunan perekonomian nasional. Ada beberapa alasan yang melatar belakangi, seperti yang dikemukanan oleh Prakoso (2000) pertama, sektor pertanian merupakan tumpuan hidup sebagian besar penduduk Indonesia; kedua, sektor pertanian merupakan penghasil kebutuhan makanan sebagian besar penduduk Indonesia, utamanya beras, sementara ketahanan pangan merupakan prasyarat utama bagi tercapainya ketahanan ekonomi maupun ketahanan politik; ketiga, sektor pertanian dengan wawasan agribisnis menempati posisi penting sebagai penyeimbang pendapatan nasional.

Menurut Arsyad (2005), pembangunan ekonomi daerah merupakan suatu proses dimana pembangunan daerah dan masyarakat mengelola sumberdaya yang ada dan membentuk suatu pola kemitraan antara pemerintah daerah dan sektor swasta untuk menciptakan suatu lapangan kerja baru dan merangsang perkembangan ekonomi dalam wilayah tersebut. Pembangunan ekonomi daerah mempunyai peran penting dalam keberhasilan pembangunan nasional. Keadaan perekonomian nasional disusun oleh keadaan perekonomian daerah (regional), sehingga keberhasilan pembangunan di tingkat daerah akan turut menentukan keberhasilan pembangunan di tingkat nasional.

Sektor pertanian di Provinsi Jawa Tengah merupakan sektor yang mempunyai keterkaitan erat dalam memperkuat ekonomi kerakyatan, upaya mengatasi pengangguran, usaha membangun ketahanan pangan, memproduksi dan membeli pangan, usaha pelestarian lingkungan dan basis pembangunan ekonomi daerah. Provinsi Jawa Tengah memiliki sumber daya pertanian yang berlimpah dan berkualitas. Jawa Tengah sangat beruntung, karena posisinya yang strategis. Selain berbatasan dengan Provinsi lain, juga diapit oleh Laut Jawa di sebelah Utara dan Samudera Indonesia di sebelah Selatan. Hal ini memperlihatkan Jawa Tengah memiliki potensi di sektor pertanian yang besar. Kebumen merupakan salah satu kabupaten yang berada di Jawa Tengah. Kondisi wilayah Kabupaten Kebumen sebagian besar adalah dataran rendah oleh karena itu pengembangan sektor pertanian sangat cocok diterapkan di daerah tersebut. Sektor pertanian merupakan sektor yang menjadi andalan di Kabupaten Kebumen. Menurut data BPS Kabupaten Kebumen tahun 2015, sektor pertanian memberikan sumbangan terbesar dibandingkan dengan sektor ekonomi lainnya dalam pembentukan PDRB Kabupaten Kebumen tahun 2015 dengan presentase sebesar 35,40\% dari total perolehan PDRB keseluruhan. Tanaman bahan pangan Kabupaten Kebumen antara lain padi, ubi jalar, kacang hijau, kacang tanah, kacang kedelai, dan jagung.

Melihat data-data tersebut menunjukkan bahwa komoditi tanaman bahan makanan yang dihasilkan di Kabupaten Kebumen memiliki potensi yang berbeda-beda. Sehingga kegiatan perencanaan pembangunan dalam meningkatkan perekonomian daerah Kabupaten Kebumen khususnya subsektor tanaman bahan pangan dapat dapat lebih baik dan terarah sesuai dengan kontribusi komoditi yang diberikan masing - masing. 


\section{KAJIAN LITERATUR}

\section{Teori Basis Ekonomi}

Teori basis ekonomi ini dikemukakan oleh Harry W. Richardson (1973) yang menyatakan bahwa faktor penentu utama pertumbuhan ekonomi suatu daerah adalah berhubungan langsung dengan permintaan akan barang dan jasa dari luar daerah (Arsyad 2005). Dalam penjelasan selanjutnya dijelaskan bahwa pertumbuhan industriindustri yang menggunakan sumberdaya lokal, termasuk tenaga kerja dan bahan baku untuk diekspor, akan menghasilkan kekayaan daerah dan penciptaan peluang kerja (job creation). Asumsi ini memberikan pengertian bahwa suatu daerah akan mempunyai sektor unggulan apabila daerah tersebut dapat memenangkan persaingan pada sektor yang sama dengan daerah lain sehingga dapat menghasilkan ekspor (Suyatno 2000:146).

Ada serangkaian teori ekonomi sebagai teori yang berusaha menjalankan perubahan-perubahan regional yang menekankan hubungan antara sektor-sektor yang terdapat dalam perekonomian daerah. Teori yang paling sederhana dan populer adalah teori basis ekonomi (economic base theory). Menurut Glasson (1990:63-64), konsep dasar basis ekonomi membagi perekonomian menjadi dua sektor yaitu:

1. Sektor-sektor Basis

Sektor basis adalah sektor-sektor yang mengekspor barang-barang dan jasa ke tempat di luar batas perekonomian masyarakat yang bersangkutan atas masukan barang dan jasa mereka kepada masyarakat yang datang dari luar perbatasan perekonomian masyarakat yang bersangkutan.

2. Sektor-sektor Non Basis

Sektor non basis adalah sektor-sektor yang menjadikan barang-barang yang dibutuhkan oleh orang yang bertempat tinggal di dalam batas perekonomian masyarakat bersangkutan. Sektor-sektor tidak mengekspor barang-barang. Ruang lingkup mereka dan daerah pasar terutama adalah bersifat lokal.

Teori basis ekonomi berupaya untuk menemukan dan mengenali aktivitas basis dari suatu wilayah, kemudian meramalkan aktivitas itu dan menganalisis dampak tambahan dari aktivitas ekspor tersebut. Konsep kunci dari teori basis ekonomi adalah bahwa kegiatan ekspor merupakan mesin pertumbuhan. Tumbuh tidaknya suatu wilayah ditentukan oleh bagaimana kinerja wilayah itu terhadap permintaan akan barang dan jasa dari luar.

\section{Analisis Location Quotien}

Metode Location Quotient(LQ) adalah metode yang membandingkan porsi lapangan kerja atau jumlah produksi atau nilai tambah untuk sektor tertentu di suatu wilayah dibandingkan dengan porsi lapangan kerja atau jumlah produksi atau nilai tambah untuk sektor yang sama secara nasional. Tujuan metode LQ ini untuk mengidentifikasi sektor unggulan(basis) dalam suatu wilayah.

Teknik analisis Location Quotient (LQ) merupakan cara permulaan untuk mengetahui kemampuan suatu daerah dalam sektor kegiatan tertentu. Cara ini tidak atau belum memberi kesimpulan akhir. Kesimpulan yang diperoleh baru merupakan kesimpulan sementara yang masih harus dikaji dan ditilik kembali melalui teknik analisis lain yang dapat menjawab apakah kesimpulan sementara di atas terbukti kebenarannya. Pada dasarnya teknik ini menyajikan perbandingan relatif antara kemampuan suatu sektor di daerah yang diselidiki dengan kemampuan sektor yang sama pada daerah yang lebih luas.

1. Jika nilai $L Q<1$, maka sektor yang bersangkutan kurang terspesialisasi dibanding sektor yang sama di tingkat daerah tertentu, sehingga bukan merupakan sektor unggulan.

2. Jika nilai $L Q=1$, sektor yang bersangkutan memiliki tingkat spesialisasi yang sama dengan sektor sejenis di tingkat daerah tertentu, sehingga hanya cukup untuk melayani kebutuhan daerah sendiri.

3. Jika nilai $L Q>1$, sektor yang bersangkutan lebih terspesialisasi dibanding sektor yang sama di tingkat daerah tertentu, sehingga merupakan sektor unggulan.

\section{Analisis Shift Share}

Shift Share adalah salah satu alat analisis untuk mengidentifikasi sumber ekonomi dari sisi tenaga kerja atau pendapatan suatu wilayah tertentu. Shift Share ini berguna untuk melihat perkembangan wilayah terhadap wilayah yang lebih luas misal perkembangan kabupaten terhadap propinsi atau propinsi terhadap nasional. 
Dengan Shift Share dapat diketahui perkembangan sektor - sektor dibanding sektor lainnya serta dapat membandingkan laju perekonomian disuatu wilayah.

\section{METODE}

\section{Rancangan Penelitian}

Pada rancangan sebuah penelitian akan dijelaskan mengenai langkah awal hingga akhir mengenai tata cara dilakukanya penelitian ini membentuk proses dan hasil yang objektif, efektif, valid, dan efisien. Secara umum tujuan penelitian ini adalah

untuk mengetahui jenis-jenis komoditas pertanian sub sektor tanaman bahan pangan yang ada di Kabupaten Kebumen dan untuk mengetahui hasil perhitungan LQ dan Shift Share mengenai komoditas pertanian sub sektor tanaman bahan pangan yang ada di Kabupaten Kebumen.

\section{Metode Pengumpulan Data}

1. Observasi

Teknik ini dilakukan dengan cara pengamatan secara langsung terhadap obyek penelitian berupa komoditi tanaman bahan makanan serta kondisi wilayah di Kabupaten Kebumen.

2. Studi Pustaka

Teknik ini dilakukan dengan menganalsis informasi dan data yang bersumber dari laporan dan buku atau literatur yang relevan dengan tujuan penelitian.

\section{Teknik Analisis Data}

1. Location Quotient (LQ)

LQ di dasarkan pada teori basis ekonomi.Tujuannya adalah menentukan sektor ekonomi basis (ekspor) dan non- basis.Dalam analisis LQ ekonomi diasumsikan tertutup. Asumsi lain, jika suatu daerah lebih berspesialisasi dibanding negara dalam menghasilkan produk tertentu (LQ>1), maka ia akan mengekspor barang tersebut. Hasil dari LQ ini akan digunakan untuk mengetahui struktur ekonomi, bukan untuk proyeksi.

$$
L Q_{i}=\frac{E_{i j} / E_{j}}{E_{i n} / E_{n}}
$$

Keterangan :

Eij = Variabel regional (contoh: hasil komoditas) sektor i di wilayah j (kabupaten)

$\mathrm{Ej}=$ Variabel regional di wilayah $\mathrm{j}$

Ein $=$ Variabel regional di sektor $\mathrm{i}$ di wilayah $\mathrm{n}$ (provinsi)

$\mathrm{En}=$ Variabel regional di wilayah $\mathrm{n}$

Analisis Hasil LQ

LQi> 1 mengindikasikan ada kegiatan ekspor di sektor tersebut atau sektor basis (B), sedangkan LQi $<1$ disebut sektor nonbasis (NB).

2. Analisis Shift Share

Analisis untuk menentukan kinerja atau produktifitas kerja perekonomian daerah dengan membandingkannya dengan daerah yang lebih besar (tingkat regional atau nasional).

\section{St $=$ Vit $-\left(V_{t} /\right.$ Va $)$ Via}

Keterangan:

Vjt= Volume dari tanaman (ton) pangan di wilayah (ex:Kabupaten) pada tahun akhir. $\mathrm{Vt}=$ Volume dari tanaman (ton) pangan di wilayah (ex: Provinsi) pada tahun akhir. 
$\mathrm{Va}=$ Volume dari tanaman (ton) pangan di wilayah (ex: Provinsi) pada tahun awal.

Vja =Volume dari tanaman (ton) pangan di wilayah (ex: Kabupaten) pada tahun awal.

Analisis Hasil Total Shift Share

Shift share positif artinya menunjukkan bahwa pertumbuhan sektor pada tingkat wilayah ke satu lebih cepat dibandingkan dengan pertumbuhan sektor pada wilayah kedua (wilayah perbandingan). Shift Share negatif artinya pertumbuhan suatu sektor pada tingkat wilayah kesatu lebih lambat dibandingkan dengan pertumbuhan sektor tersebut pada wilayah kedua (wilayah perbandingan).

\section{HASIL DAN PEMBAHASAN}

\section{Data Hasil Produksi Sub Sektor Tanaman Bahan Pangan di Kabupaten Kebumen}

Tabel 4.1 adalah hasil sub sektor tanaman bahan pangan di Provinsi Jawa Tengah menurut Kebumen Dalam Angka Badan Pusat Statistik Provinsi Jawa Tengah. Berikut adalah jumlah (ton) pada masing-masing komoditas.

Tabel 1. Hasil Produksi Sub Sektor Tanaman Bahan Pangan di Provinsi Jawa Tengah

\begin{tabular}{crrrrrrr}
\hline \multirow{2}{*}{ Tahun } & \multicolumn{7}{c}{ Komoditas } \\
\cline { 2 - 8 } & $\begin{array}{c}\text { Padi } \\
\text { sawah }\end{array}$ & Jagung & Ubi Kayu & $\begin{array}{c}\text { Ubi } \\
\text { Jalar }\end{array}$ & $\begin{array}{c}\text { Kacang } \\
\text { tanah }\end{array}$ & Kedelai & $\begin{array}{c}\text { Kacang } \\
\text { Hijau }\end{array}$ \\
\hline 2013 & 10.007 .562 & 2.930 .911 & 4.089 .635 & 183.694 & 120.158 & 99.318 & 64.277 \\
2014 & 9.294 .475 & 3.051 .516 & 3.977 .810 & 179.394 & 128.030 & 125.466 & 96.219 \\
2015 & 11.006 .570 & 3.212 .391 & 129.794 & 151.312 & 109.204 & 98.992 & 98.992 \\
2016 & 11.006 .570 & 3.212 .391 & 3.571 .594 & 151.312 & 109.204 & 129.794 & 98.992 \\
2017 & 11.067 .606 & 3.577 .507 & 3.138 .864 & 145.068 & 91.234 & 105.553 & 123.229 \\
\hline Rata-Rata & 10.476 .557 & 3.196 .943 & 2.981 .539 & 162.156 & 111.566 & 111.825 & 96.342 \\
\hline$\%$ & $61,13 \%$ & $18,66 \%$ & $17,40 \%$ & $0,95 \%$ & $0,65 \%$ & $0,65 \%$ & $0,56 \%$ \\
\hline
\end{tabular}

Sumber : BPS Provinsi Jawa Tengah dan Jawa Tengah Dalam Angka tahun 2014 -2018

Berdasarkan informasi pada tabel 1 diketahui bahwa rata-rata tertinggi untuk produksi produk tanaman pangan di Provinsi Jawa Tengah adalah produk padi (61,13\%). Selanjutnya produksi terbesar kedua adalah tanaman jagung $(18,66 \%)$ dan ketiga tanaman Ubi kayu $(17,4 \%)$.

\section{Data Hasil Produksi Sub Sektor Tanaman Bahan Pangan di Kabupaten Kebumen}

Tabel 2. Hasil Produksi Sub Sektor Tanaman Bahan Pangan di Kabupaten Kebumen

\begin{tabular}{|c|c|c|c|c|c|c|c|}
\hline \multirow[b]{2}{*}{ Tahun } & \multicolumn{7}{|c|}{ Komoditas } \\
\hline & Padi sawah & Jagung & Ubi Kayu & $\begin{array}{c}\text { Ubi } \\
\text { Jalar }\end{array}$ & $\begin{array}{c}\text { Kacang } \\
\text { tanah }\end{array}$ & Kedelai & $\begin{array}{c}\text { Kacang } \\
\text { Hijau }\end{array}$ \\
\hline 2013 & $397.437,61$ & $29.189,14$ & $139.674,50$ & 932,72 & $2.964,26$ & $4.539,33$ & $7.093,71$ \\
\hline 2014 & $407.940,26$ & $23.414,91$ & $124.659,71$ & $1.059,21$ & $2.607,20$ & $8.464,98$ & $9.469,01$ \\
\hline 2015 & $486.969,00$ & $42.479,00$ & $167.521,00$ & 982,00 & $2.427,00$ & $7.529,07$ & $13.619,00$ \\
\hline 2016 & $446.946,03$ & $26.909,79$ & $87.816,33$ & 507,99 & $2.069,08$ & 645,71 & 178,97 \\
\hline 2017 & $411.387,62$ & $32.931,06$ & $80.620,14$ & 799,00 & $2.287,30$ & $2.449,53$ & $12.375,12$ \\
\hline Rata-rata & $2.150 .680,52$ & $154.923,90$ & $600.291,68$ & $4.280,92$ & $12.354,84$ & $23.628,62$ & $42.735,81$ \\
\hline$\%$ & $71,96 \%$ & $5,18 \%$ & $20,08 \%$ & $0,14 \%$ & $0,41 \%$ & $0,79 \%$ & $1,43 \%$ \\
\hline
\end{tabular}

Sumber: BPS Kabupaten Kebumen dan Kabupaten Kebumen Dalam Angka tahun 2013-2015

Data pada tabel 2. menunjukkan rata-rata produksi tanaman pangan tertinggi adalah produk padi sawah (71,96\%), sedangkan produk unggulan kedua adalah ubi kayu (20,08\%). Berdasarkan hasil analisis dan penelusuran data, diketahui kecamatan penghasil padi terbesar di kabupaten Kebumen pada tahun 2017 adalah Kecamatan Ambal, Kecamatan Puring, dan Kecamatan Kebumen. Sedangkan kecamatan penghasil Ubi kayu terbesar adalah Kecamatan Karanggayam, Kecamatan Sempor dan Karangsambung. 


\section{Perhitungan Analisis Location Qoutient (LQ)}

Adapun hasil produksi sektor pertanian di Kabupaten tahun 2017

Tabel 3. Analisis Location Qoutient (LQ) Hasil Produksi Tanaman Pangan Tahun 2017 Kabupaten Kebumen

\begin{tabular}{|c|c|c|c|c|c|}
\hline \multirow[t]{2}{*}{$\begin{array}{c}\text { Jenis } \\
\text { Komoditas }\end{array}$} & \multirow{2}{*}{$\begin{array}{c}\begin{array}{c}\text { Kabupaten } \\
\text { Kebumen } \\
\text { (ton) }\end{array} \\
\text { (a) } \\
\end{array}$} & \multirow{2}{*}{$\begin{array}{c}\text { Provinsi Jawa } \\
\text { Tengah (ton) } \\
\text { (b) }\end{array}$} & \multicolumn{3}{|c|}{ Location Qoutient (LQ) } \\
\hline & & & $(c)=(a /$ tot $)$ & $(d)=(b / t o t)$ & $(\mathrm{c}) /(\mathrm{d})$ \\
\hline Padi sawah & $411.387,62$ & 11.067 .606 & 0,606475 & 0,757829593 & 0,80 \\
\hline Jagung & $32.931,06$ & 3.577 .507 & 0,196038 & 0,060663303 & 3,23 \\
\hline Ubi Kayu & $80.620,14$ & 3.138 .864 & 0,172001 & 0,148512801 & 1,16 \\
\hline Ubi Jalar & 799,00 & 145.068 & 0,007949 & 0,001471862 & 5,40 \\
\hline Kacang tanah & $2.287,30$ & 91.234 & 0,004999 & 0,004213505 & 1,19 \\
\hline Kedelai & $2.449,53$ & 105.553 & 0,005784 & 0,004512353 & 1,28 \\
\hline Kacang Hijau & $12.375,12$ & 123.229 & 0,006753 & 0,022796583 & 0,30 \\
\hline Total & $581.831,27$ & $17.495 .555,00$ & & & \\
\hline
\end{tabular}

Berdasarkan tabel 3 diketahui bahwa komoditas Jagung, Ubi kayu, Ubi Jalar, Kacang Tanah dan Kedelai memiliki angka LQ> 1. Hasil ini menggambarkan lima produk ini menjadi produk basis. Hal ini berarti kelima komoditas ini memiliki spesialisasi dibandingkan dengan produk lainnya dalam paramateri produksi di wilayah Provinsi. Produk dengan nilai LQ tertinggi pada tahun 2017 adalah produk ubi jalar $(5,40)$ dan jagung $(3,23)$ sehingga produk ini menjadi salah satu produk yang berpotensi menjadi unggulan daerah Kabupaten Kebumen. Selain itu, komoditas ini juga mampu mencukupi kebutuhan wilayah yang lain. Komoditas dengan nilai LQ terendah yaitu komoditas padi $(0,8)$ dan kacang hijau $(0,3)$. Komoditas ini tidak mampu menjadi komditas unggulan daerah dan pasokan bagi wilayah lain.

\section{Perhitungan Analisis Shift Share}

Analisis Shift Share ini digunakan untuk menganalisis perubahan struktur ekonomi Kabupaten Kebumen relatif terhadap struktur ekonomi wilayah adaministratif yang lebih tinggi (Propinsi Jawa Tengah) sebagai referensi atau acuan.

Tabel 4. Analisis Shift Share Produksi Tanaman Pangan Tahun 2013 - 2017 Kabupaten Kebumen Terhadap Provinsi Jawa Tengah

\begin{tabular}{|c|c|c|c|c|c|c|c|c|}
\hline Komoditas & Tahun & Padi sawah & Jagung & Ubi Kayu & $\begin{array}{c}\text { Ubi } \\
\text { Jalar }\end{array}$ & $\begin{array}{c}\text { Kacang } \\
\text { tanah }\end{array}$ & Kedelai & $\begin{array}{c}\text { Kacang } \\
\text { Hijau }\end{array}$ \\
\hline \multirow{5}{*}{$\begin{array}{l}\text { Provinsi } \\
\text { Jawa } \\
\text { Tengah }\end{array}$} & 2013 & $397.437,61$ & $29.189,14$ & $139.674,50$ & 932,72 & $2.964,26$ & $4.539,33$ & $7.093,71$ \\
\hline & 2014 & $407.940,26$ & $23.414,91$ & $124.659,71$ & $1.059,21$ & $2.607,20$ & $8.464,98$ & $9.469,01$ \\
\hline & 2015 & $486.969,00$ & $42.479,00$ & $167.521,00$ & 982 & $2.427,00$ & $7.529,07$ & $13.619,00$ \\
\hline & 2016 & $446.946,03$ & $26.909,79$ & $87.816,33$ & 507,99 & $2.069,08$ & 645,71 & 178,97 \\
\hline & 2017 & $411.387,62$ & $32.931,06$ & $80.620,14$ & 799 & $2.287,30$ & $2.449,53$ & $12.375,12$ \\
\hline \multirow{5}{*}{$\begin{array}{l}\text { Kabupaten } \\
\text { Kebumen }\end{array}$} & 2013 & 10.007 .562 & 2.930 .911 & 4.089 .635 & 183.694 & 120.158 & 99.318 & 64.277 \\
\hline & 2014 & 9.294 .475 & 3.051 .516 & 3.977 .810 & 179.394 & 128.030 & 125.466 & 96.219 \\
\hline & 2015 & 11.006 .570 & 3.212 .391 & 129.794 & 151.312 & 9.204 & 98.992 & 98.992 \\
\hline & 2016 & 11.006 .570 & 3.212 .391 & 3.571 .594 & 151.312 & 109.204 & 129.794 & 98.992 \\
\hline & 2017 & 11.067 .606 & 3.577 .507 & 3.138 .864 & 145.068 & 91.234 & 105.553 & 123.229 \\
\hline \multicolumn{2}{|l|}{ Vjt } & 11.067 .606 & 3.577 .507 & 3.138 .864 & 145.068 & 91.234 & 105.553 & 123.229 \\
\hline \multicolumn{2}{|l|}{$\mathrm{Vt} / \mathrm{va}$} & 1,035 & 1,128 & 0,577 & 0,857 & 0,772 & 0,540 & 1,745 \\
\hline \multicolumn{2}{|l|}{ Vja } & 10.007 .562 & 2.930 .911 & 4.089 .635 & 183.694 & 120.158 & 99.318 & 64.277 \\
\hline \multicolumn{2}{|c|}{$(\mathrm{Vt} / \mathrm{Va})^{*} \mathrm{Vja}$} & 10.358 .826 & 3.306 .640 & 2.360 .537 & 157.358 & 92.717 & 53.594 & 112.132 \\
\hline \multicolumn{2}{|c|}{ St } & 708.780 & 270.866 & 778.326 & -12.291 & -1.483 & 51.959 & 11.096 \\
\hline
\end{tabular}


Berdasarkan informasi pada tabel 4 diketahui bahwa ubi jalar (-12.291) dan kacang tanah (-1.483) memiliki angka negatif < 1menunjukkan bahwa pertumbuhan produk ubi jalar dan kacang tanah di Kabupaten Kebumen lebih lambat dibandingkan dengan pertumbuhan produk ubi jalar dan kacang tanah pada Provinsi Jawa Tengah

Produk Ubi Jalar (778.326), Padi Sawah (707.780), Jagung (270.866), Kedelai (51.959), dan Kacang Hijau (11.096) memiliki angka positif $>1$ menunjukkan bahwa pertumbuhan produk tersebut di Kabupaten Kebumen lebih cepat dibandingkan dengan pertumbuhan produk ubi jalar dan kacang tanah pada Provinsi Jawa Tengah

\section{SIMPULAN}

Komoditas Jagung, Ubi kayu, Ubi Jalar, Kacang Tanah dan Kedelai memiliki angka LQ>1. Hasil ini menggambarkan lima produk ini menjadi produk basis. Hal ini berarti kelima komoditas ini memiliki spesialisasi dibandingkan dengan produk lainnya dalam paramateri produksi di wilayah Provinsi. Produk dengan nilai LQ tertinggi pada tahun 2017 adalah produk ubi jalar $(5,40)$ dan jagung $(3,23)$ sehingga produk ini menjadi salah satu produk yang berpotensi menjadi unggulan daerah Kabupaten Kebumen. Selain itu, komoditas ini juga mampu mencukupi kebutuhan wilayah yang lain. Komoditas dengan nilai LQ terendah dan bukan merupakan sektor non basis adalah komoditas padi $(0,8)$ dan kacang hijau $(0,3)$. Komoditas ini tidak mampu menjadi komditas unggulan daerah dan pasokan bagi wilayah lain.

Produk Ubi Jalar (778.326), Padi Sawah (707.780), Jagung (270.866), Kedelai (51.959), dan Kacang Hijau (11.096) memiliki angka positif $>1$ menunjukkan bahwa pertumbuhan produk tersebut di Kabupaten Kebumen lebih cepat dibandingkan dengan pertumbuhan produk ubi jalar dan kacang tanah pada Provinsi Jawa Tengah

\section{REFERENSI}

Arsyad, L. (2005). Pengantar Perencanaan Pembanguna Ekonomi. Daerah Edisi Kedua, BPFE, Yogyakarta.

Badan Pusat Statistik (2013). Kebumen Dalam Angka, 2013. Badan Pusat Statistik Kabupaten Kebumen. Kebumen.

Badan Pusat Statistik (2014). Kebumen Dalam Angka, 2014. Badan Pusat Statistik Kabupaten Kebumen. Kebumen.

Badan Pusat Statistik (2015). Kebumen Dalam Angka, 2015. Badan Pusat Statistik Kabupaten Kebumen. Kebumen.

Badan Pusat Statistik (2016). Kebumen Dalam Angka, 2016. Badan Pusat Statistik Kabupaten Kebumen. Kebumen.

Badan Pusat Statistik (2016). Kebumen Dalam Angka, 2016. Badan Pusat Statistik Kabupaten Kebumen. Kebumen.

Adisasmita, R. (2005). Dasar-Dasar Ekonomi Wilayah. Yogyakarta: Graha Ilmu.

Nugroho, B. A. (2017). Analisis Sektor Unggulan Kabupaten Kutai Kartanegara Tahun 2010-2014. GERBANG ETAM, 11(1).

Sapriadi, S., \& Hasbiullah, H. (2015). Analisis Penentuan Sektor Unggulan Perekonomian Kabupaten Bulukumba. Jurnal lqtisaduna, 1(1), 53-71.

Suharna, N. (1993). Keberadaan Basidiomycetes di Cagar Alam Bantimurung, Karaenta dan Sekitarnya, Maros, Sulawesi Selatan. In Prosiding Seminar Hasil Litbang SDH (Vol. 2). 
Suyatno, S. (2007). Analisa Economic Base Terhadap Pertumbuhan Ekonomi Daerah Tingkat II Wonogiri: Menghadapiimplementasi UU No. 22/1999 Dan UU No. 5/1999. Jurnal Ekonomi Pembangunan: Kajian Masalah Ekonomi dan Pembangunan, 1(2), 144-159.

Tarigan, R. (2005). Perencanaan Pembangunan Wilayah Edisi Revisi. Jakarta (ID). Bumi Aksara.

Tuandali, D. F. N. (2017). Analisis Pergeseran Struktur Ekonomi dan Sektor Unggulan Kabupaten Halmahera Utara Provinsi Maluku Utara Periode 2010-2014. Jurnal Berkala Ilmiah Efisiensi, 17(01). 